\title{
A Case of Hemoglobinuria in P.Vivax Malaria
}

\author{
Stephen Samuel*, Pramod R. Jha** \\ $* 3^{\text {rd }}$ year Medicine Resident, **Professor of Medicine \\ Dhiraj Hospital, Sumandeep Vidhyapeeth University, Pipariya, Vadodara, India
}

\begin{abstract}
Most of the research and published literature onmalaria focus on $P$. falciparum and much less on $P$. vivax. Renal failure is a feature of blackwater fever, where hemoglobin from lysed red blood cells leaks into the urine. Here we would like to report an unusual case of hemoglobinuria in P.vivax malaria patient.
\end{abstract}

Keywords: P.vivax, Hemoglobinuria, cola coloured urine

\section{Introduction}

Malaria is a life-threatening disease caused by plasmodium transmitted to humans through the bite of the Anopheles mosquito. Once an infected mosquito bites a human being and transmits the parasites, those parasites multiply in the host's liver before infecting and destroying red blood cells.Although the exact burden of disease caused by P. vivax infection is still a matter of debate, this parasite causes approximately 100-300 million cases registeredeach year ${ }^{[1,2]}$. Moreover, the appearance of chloroquine resistance in $\mathrm{P}$. vivax parasites, the lack of primaquine alternatives to attack the dormant liver-stage hypnozoites, documentation of cases of severe disease, and increasing temperature caused by climate change increase concern for a future increase of this disease ${ }^{[3]}$.However, it has been observed in previous cases, it has become evident that P.vivax monoinfection could also be involved in multiple organ dysfunction and severe life-threatening disease as seen in P. falciparum infection $[4,5]$

Haemoglobinuria is a condition in which the oxygen transport protein haemoglobin is found in abnormally high concentrations in the urine.The condition is often associated with haemolytic anaemia in which the red blood cells (RBCs) are destroyed, thereby increasing levels of free plasma hemoglobin. Excess haemoglobin is filtered by the kidneyswhich gets excreted into the urine, giving urine a cola colour ${ }^{[8]}$.

\section{Case Presentation}

A 45 year old male person working as a night shift workerwith lower socio economic status came to Dhiraj General Hospital, Pipariya, Vadodara with chief complains of high grade fever of 4-5 days associated with chills and rigors with malaise \& bodyache. He noticed red coloured urine for 2 days without any burning sensation while micturating. He reported taking no medication before coming to the hospital.

Patient gave no h/oof cough, dyspnoea, abdominal pain, loose stools, anorexia and weight loss.

\section{Examination}

Patient was conscious, co-operative and oriented to time, place \& person, well built and nourished.

\author{
Temperature - Febrile \\ Pulse-100/ min \\ Resp rate- $20 / \mathrm{min}$
}

- Blood pressure was - 100/62 mmHg

- Pallor mild grade

- Noclubbing/ cyanosis/ icterus/pedal oedema/ lymphadenopathy

- Systemic examination- R/S: air entry equal on both the sides \& clear, CVS- S1S2 heard, no murmur,

P/A- soft nontender; splenomegaly 2 fingers palpated below costal margin, CNS- conscious \&oriented.

Patient was admitted on this history suspecting as acute febrile illness probably Malaria with hemoglobinuria.

Investigation:

\begin{tabular}{|c|c|}
\hline$\overline{\mathrm{CBC}}$ & 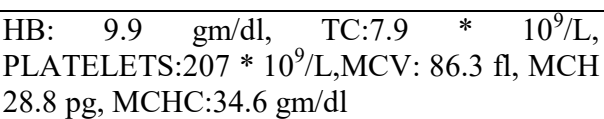 \\
\hline $\begin{array}{l}\text { Malaria } \\
\text { parasite }\end{array}$ & $\begin{array}{l}\text { Malaria parasite was positive for a malaria and } \\
\text { malaria antigen was also positive with P.vivax } \\
\text { schizonts and ring forms. }\end{array}$ \\
\hline Urine routine & $\begin{array}{l}\text { Albumin }++++ \text {, sugar-absent, pus cell } 1-2 \\
\text { wbc/hpf- .A urinary dipstick test was positive } \\
\text { for blood but microscopical examination } \\
\text { showed no red blood cells and RBC cast. }\end{array}$ \\
\hline S. electrolytes & 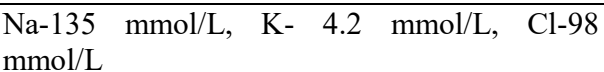 \\
\hline $\begin{array}{l}\text { Renal } \\
\text { function }\end{array}$ & $\begin{array}{l}\text { Serum creatinine } 0.7 \mathrm{mg} / \mathrm{dl} \text {, blood urea } 27 \\
\mathrm{mg} / \mathrm{dl}\end{array}$ \\
\hline liver function & $\begin{array}{l}\text { SGPT-23 U/L; SGOT - } 19 \mathrm{U} / \mathrm{L} ; \text { S.Bilirubin - } \\
0.4 \mathrm{mg} / \mathrm{dl} \text {; direct }-0.2 \mathrm{mg} / \mathrm{dl} \text {;indirect }-0.2 \mathrm{mg} / \mathrm{dl} \text {. }\end{array}$ \\
\hline total protein & $\begin{array}{l}6.90 \mathrm{gm} / \mathrm{dl} ; \text { albumin }-4.4 \mathrm{gm} / \mathrm{dl} ; \mathrm{globulin}-2.50 \\
\mathrm{gm} / \mathrm{dl} \mathrm{A} / \mathrm{G}-1.76\end{array}$ \\
\hline S.TSH & $2.85 \mathrm{mIU} / \mathrm{L}$ \\
\hline Serology & $\begin{array}{l}\text { HIV-negative; HBsAG - negative; HCV - } \\
\text { negative }\end{array}$ \\
\hline Lipid profile & 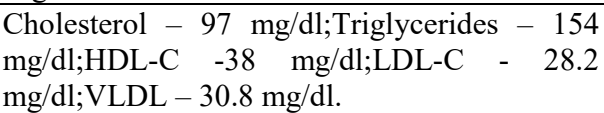 \\
\hline
\end{tabular}

His condition improved on treatment with injectable artesunate $(2.4 \mathrm{mg} / \mathrm{kg}$ body weight stat IV followed by $2.4 \mathrm{mg} / \mathrm{kg}$ body weight at 12 and 24 hours and then daily once a day for 2 days.) Initially administered intravenously. Normal liver function and normal G6PD activity were seen in the patient. Patient was also managed

\section{Volume 6 Issue 1, January 2017




\section{International Journal of Science and Research (IJSR) \\ ISSN (Online): 2319-7064}

Index Copernicus Value (2015): 78.96 | Impact Factor (2015): 6.391

IV fluids, antipyretics.He stayed in the hospital for 72 hours.

The absence of urine RBCs and RBC casts microscopically despite a positive dipstick test suggests hemoglobinuria or myoglobinuria.

\section{Discussion}

Malaria is an endemic illness in our country .The most common type of malaria is P.vivax malaria however majority of the complications are attributed to P.falciparum malaria. Blackwater fever is a complication of malaria infection in which red blood cells burst in the bloodstream (hemolysis), releasing hemoglobin directly into the blood vessels and this hemoglobin is filtered by the kidneys and passed into the urine, frequently leading to kidney failure.Blackwater fever has a high mortality. Its symptoms include a rapid pulse, high fever and chills, extreme prostration, a rapidly developing anaemia, and the passage of urine that is black or dark red in colour (hence the disease's name). The distinctive colour of the urine is due to the presence of large amounts of hemoglobin, released during the extensive destruction of the patient's red blood cells by malarial parasites. Patients frequently develop anaemia because of the low numbers of red blood cells. The presence of blood pigments in the blood serum usually produces jaundice early in the course of the disease $^{[8]}$.

The patient in this report developed significant haemolysis, leading to visible hemoglobinuria.

Previously cases of hemoglobinuria were reported in a patient with P.falciparum and rarely in a case of P.vivax malarial infection ${ }^{[9]}$. This report adds further evidence that malaria due to P.vivax is not always 'benign' \& it can cause major complications.

\section{Conclusion}

The physician should be vigilant about this when treating a case of malaria with patient complaining of passing cola coloured urine, it can be caused by P.vivax malaria.

Plasmodium vivax can cause debilitating febrile illness, but vital organ damage and severe haemolysis are very unusual. Previous reported cases of Blackwater fever states that it seldom appears until a person has had at least four attacks of malaria and has been in an endemic area for six monthshowever while observing our patient we can deduce that it can even present when patient presents with first attack of P.vivax malaria ${ }^{[8]}$.

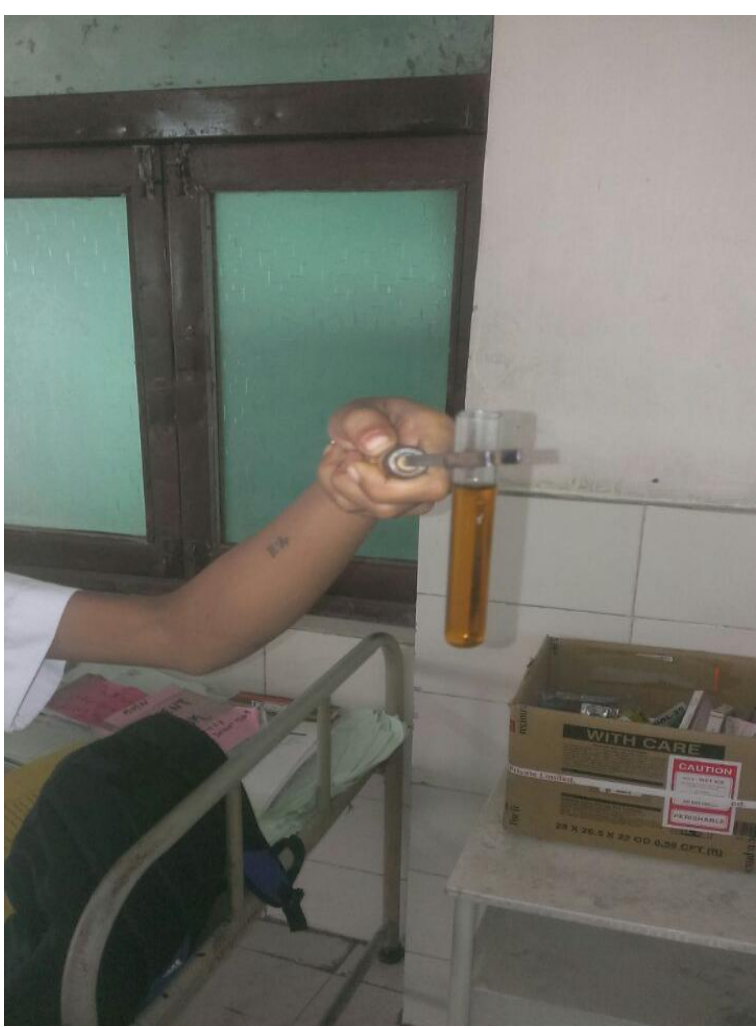

Figure 1.1: Cola coloured urine specimen

\section{References}

[1] Ashwani Kumar, Neena Valecha, Tanu Jain, Aditya P. Dash. Burden of Malaria in India: Retrospective and Prospective View. Am J Trop Med Hyg.2007;77(6_Suppl):69-

78.FullTextat http://www.ajtmh.org/cgi/reprint/77/6 Suppl/69

[2] PB Health. National Vector Borne Disease Control Progrmme.

Available at http://pbhealth.gov.in/pdf/malaria.pdf

[3] Marcelo U. Ferreira Email author and Marcia C. Castro Email author;Malaria Journal201615:284DOI: 10.1186/s12936-016-1335-1

[4] Malaria situation. National Vector Borne Disease control Programme. Available at http://nvbdcp.gov.in/Doc/mal_situation_Jan2015.p df

[5] Barbara S, 2002. Focus on Plasmodium vivax. Trends Parasitol 18: 287-289.

[6] Piscot S, 2006. Is Plasmodium vivax still a paradigm for uncomplicated malaria? Med Mal Infect 36: 406413.

[7] Chanthap Lon, Michele Spring, Somethy Sok, Soklyda Chann, Malar J. 2014; 13: 96.Published online 2014 Mar 14. doi: 10.1186/1475-2875-13-96

[8] Hemoglobinuria with Malaria, Martin Tombe, M.D;N Engl J Med 2008; 358:1837April 24, 2008DOI: 10.1056/NEJMicm070121

[9] McPherson RA, Ben-Ezra J, Zhao S. Basic examination of urine. In: McPherson RA, Pincus MR, eds. Henry's Clinical Diagnosis and Management by Laboratory Methods. 22nd ed. Philadelphia, PA: Elsevier Saunders; 2011: chap 28 